\title{
Rhodium-catalyzed asymmetric reactions with a dynamic library of chiral tropos phosphorus ligands*
}

\author{
Cesare Gennari ${ }^{1,}$, Chiara Monti ${ }^{1}$, and Umberto Piarulli ${ }^{2}$ \\ ${ }^{1}$ Dipartimento di Chimica Organica e Industriale, Centro di Eccellenza C.I.S.I., \\ Università degli Studi di Milano, Istituto di Scienze e Tecnologie Molecolari (ISTM) \\ del CNR, Via G. Venezian 21, 20133 Milano, Italy; ${ }^{2}$ Dipartimento di Scienze \\ Chimiche e Ambientali, Università degli Studi dell'Insubria, Via Valleggio 11, \\ 22100 Como, Italy
}

\begin{abstract}
Nineteen chiral tropos phosphorus ligands, based on a flexible (tropos) biphenol unit and a chiral P-bound alcohol (11 phosphites) or secondary amine (8 phosphoramidites), were screened, individually and as a combination of two, in various Rh-catalyzed asymmetric reactions. In the Rh-catalyzed asymmetric conjugate addition of phenylboronic acid to cyclic enones, enantiomeric excesses (ee's) up to $95 \%$ were obtained with a 1:1 mixture of a phosphite [derived from $(1 R, 2 S)$-2-(1-methyl-1-phenylethyl)cyclohexanol] and a phosphoramidite [derived from $(S, S)$-2,5-diphenylpyrrolidine]. In the mixed $\mathrm{Rh}$ precatalyst, which was characterized via ${ }^{31} \mathrm{P}-\mathrm{NMR}$, the biphenol-derived phosphite is free to rotate (tropos) while the biphenol-derived phosphoramidite shows a temperature-dependent tropos/atropos behavior (coalescence temperature $=310 \mathrm{~K}$ ). The ligands were also screened in the hydrogenation of dehydro- $\alpha$-amino acids and dehydro- $\beta$-amino acids. Ee's up to $98 \%$ were obtained for the dehydro- $\alpha$-amino acids, using the combination of a phosphite [derived from $(1 R, 2 S)$-2-phenyl-1-cyclohexanol] and a phosphoramidite [derived from $(S, S)$-bis( $\alpha$-methylbenzyl)amine]. The reaction was optimized by lowering the phosphite/phosphoramidite ratio to $0.25: 1.75$ with a resulting improvement of the product ee.
\end{abstract}

Keywords: asymmetric catalysis; combinatorial catalysis; P-ligands; atropisomerism; rhodium; hydrogenation; Michael addition.

\section{INTRODUCTION}

The scene of asymmetric catalysis has been dominated for three decades (1970-2000) by chiral bisphosphorus ligands (DIOP, DIPAMP, BINAP, DUPHOS, PENNPHOS, etc.) since the pioneering work of Knowles, Kagan, and Noyori [1]. Only recently (2000-2005), monodentate P-ligands have been applied successfully in combination with different metal sources ( $\mathrm{Rh}, \mathrm{Cu}, \mathrm{Ru}, \mathrm{Ir}, \mathrm{Pd})$ in a number of reactions (including hydrogenation, allylic substitution, conjugate addition, allylation, etc.) providing high enantioselectivities, sometimes even higher than the bidentate ligands [2]. In particular, readily accessible and highly diverse chiral monodentate ligands such as phosphoramidites, phosphites, and phosphonites have been introduced, which comprise different units attached to the phosphorus atom: a chi-

*Pure Appl. Chem. 78, 197-523. An issue of reviews and research papers based on lectures presented at the $13^{\text {th }}$ IUPAC International Symposium on Organometallic Chemistry Directed Towards Organic Synthesis (OMCOS-13), Geneva, Switzerland, 17-21 July 2005.

‡Corresponding author: E-mail: cesare.gennari@unimi.it 
ral diol (often with a stereogenic axis, e.g., binaphthol) and a N-, O-, or C-substituent, which may contain additional stereogenic elements (stereocenters). Alternatively, a cheap and flexible (tropos) biphenol unit and a P-bound chiral alcohol or secondary amine have been used [3].

An important breakthrough in this area was recently made independently by Reetz and coworkers [4] and Feringa and coworkers [5], who used a mixture of chiral monodentate P-ligands. By mixing two ligands $\left(\mathrm{L}^{\mathrm{a}}\right.$ and $\left.\mathrm{L}^{\mathrm{b}}\right)$ in the presence of $\mathrm{Rh}$, three species can be formed in various ratios: $R \mathrm{LL}^{\mathrm{a}} \mathrm{L}^{\mathrm{a}}$, $\mathrm{RhL}^{b} \mathrm{~L}^{\mathrm{b}}$, and $\mathrm{RhL}^{\mathrm{a}} \mathrm{L}^{\mathrm{b}}[6]$. The heterocombinations allowed for better yields and enantioselectivities compared to the corresponding homocombinations [4,5]. Usually, mixtures of two chiral monodentate P-ligands (binaphthol-based) were used, but also mixtures of a chiral and an achiral P-ligand were recently tested with some success $[4 b, 4 c, 5 b, 5 c]$.

Nineteen chiral tropos phosphorus ligands, based on a flexible (tropos) biphenol unit and a chiral P-bound alcohol (11 phosphites) or secondary amine (8 phosphoramidites), were recently synthesized and used in the Rh-catalyzed asymmetric hydrogenation of prochiral olefins [7]. These ligands exist as a mixture of two rapidly interconverting diastereomers, $\mathrm{L}^{\mathrm{a}}$ and $\mathrm{L}^{\mathrm{a}}$, differing in the conformation of the biphenol unit and not discernible on the NMR time scale (Fig. 1). Upon complexation with Rh, the ligand ( $L^{a}$ in equilibrium with $L^{a^{\prime}}$ ) should give rise to three different species, namely, $R h L^{a} L^{a}, R h L^{a} L^{a^{\prime}}$,

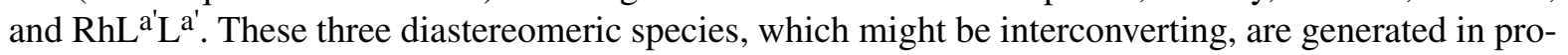
portions which most likely differ from the statistical value (1:2:1). The novelty of our approach consists in the use of a combination of two of these ligands ( $\mathrm{L}^{\mathrm{a}}$ in equilibrium with $\mathrm{L}^{\mathrm{a}}$ and $\mathrm{L}^{\mathrm{b}}$ in equilibrium with $\mathrm{L}^{\mathrm{b}}$ ) resulting in the generation of a dynamic "in situ" library, with up to 10 different species the-

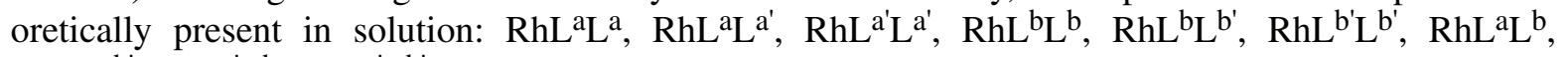
$R h L^{a} L^{b^{\prime}}, R_{L} L^{a^{\prime}} L^{b}, R h L^{a^{\prime}} L^{b^{\prime}}$. Although each species could, in principle, be present and catalyze the reaction, one of them could overcome the others, determining the direction and the extent of the enantioselectivity. 
<smiles>[R]c1cc([R])c2c(c1)-c1cc([R])cc([R])c1-c1cc([R])cc([R])c1OP([Y4])O2</smiles>
(aR) $\quad \mathbf{L}^{\mathrm{a}}$ (aS) $\mathbf{L}^{\mathbf{a}^{\prime}}$<smiles>CC1CCC(C(C)OP(=O)(O)O)C(Op2oc3ccccc3c3ccccc3o2)C1</smiles><smiles>CC(C)C1CC[C@@H](C)C[C@H]1Op1oc2ccccc2c2ccccc2o1</smiles><smiles>CC(C)(c1ccccc1)[C@H]1CCCCC1Op1oc2ccccc2c2ccccc2o1</smiles>

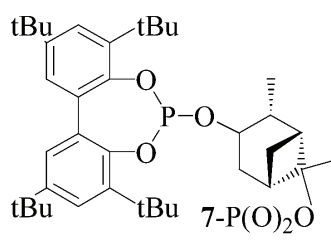

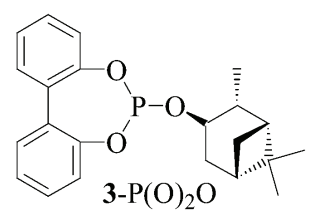
$\mathrm{R}=\mathrm{H}, t \mathrm{Bu}, \mathrm{Me}$ $\mathrm{X}^{*}=$ secondary amine or alcohol, containing stereocenters

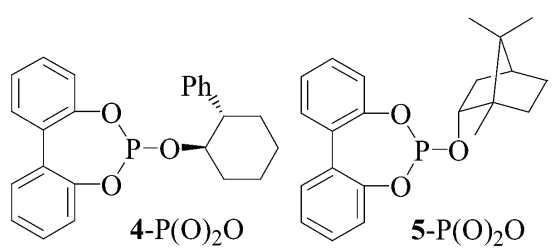<smiles>CC(C)Cc1cc(Br)cc2c1op(O[C@H]1CC[C@H](C(C)(C)C)CC1)oc1c(C(C)C)cc(C(C)(C)C)cc12</smiles><smiles>OOCC1C2CCC(C2)C1Op1oc2ccccc2c2cccc(O)c2o1</smiles><smiles>Cc1cc(C)c2op(OC3CC4CCC3(C)C4(C)C)oc3c(C)cc(C)cc3c2c1</smiles><smiles>CC(c1ccccc1)N([C@H](C)c1ccccc1)p1oc2ccccc2c2ccccc2o1</smiles>

$12-\mathrm{P}(\mathrm{O})_{2} \mathrm{~N}$

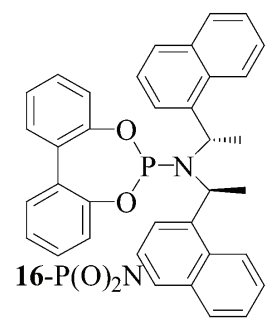

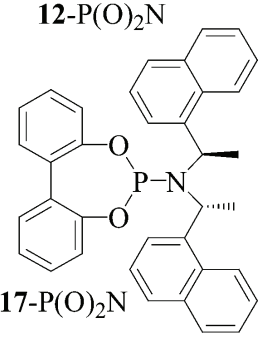<smiles>C[C@H](c1ccccc1)N(C)p1oc2ccccc2c2ccccc2o1</smiles><smiles>CC(c1ccccc1)N(C)p1oc2ccccc2c2ccccc2o1</smiles><smiles></smiles>

19- $\mathrm{P}(\mathrm{O})_{2} \mathrm{~N}$

Fig. 1 Chiral tropos P-ligands.

\section{RHODIUM-CATALYZED ASYMMETRIC CONJUGATE ADDITION OF PHENYLBORONIC ACID TO CYCLIC ENONES}

The asymmetric $\mathrm{Rh}$-catalyzed conjugate addition of aryl- and vinylboronic acids, originally reported by Miyaura and Hayashi, has become the method of choice for the stereoselective introduction of an aryl or a vinyl group in the $\beta$ position of a variety of electron-deficient olefins [8]. Excellent enantioselectivities were obtained using both bidentate (binap, segphos, chiraphos, diphosphonites, diphosphites, amidomonophosphines, chiral dienes, chiral phosphine-olefins) and, more recently, monodentate ligands (binaphtholic phosphoramidites) [9].

The ligand collection (Fig. 1) was screened in the conjugate addition of phenylboronic acid to 2-cyclohexenone 21, using $1.5 \mathrm{~mol} \%\left[\mathrm{Rh}\left(\mathrm{C}_{2} \mathrm{H}_{4}\right)_{2} \mathrm{Cl}\right]_{2}$ and a total of $6 \mathrm{~mol} \%$ of ligands $(\mathrm{Rh}: \mathrm{L}=1: 2)$ [7c]. The reaction was performed using $\mathrm{KOH}$ (1 equiv) as base [10], in a 10:1 dioxane/water solution at room temperature overnight. A few selected results are presented in Table 1. In general, when the chiral ligands were used individually (homocombinations) the phosphites gave catalysts more efficient and enantioselective than the phosphoramidites. However, the enantiomeric excesses (ee's) were only moderate, and the best ee was $70 \%$ with phosphite 6- $\mathrm{P}(\mathrm{O})_{2} \mathrm{O}$ (Table 1, entry 1). Mixtures of a phosphite and a phosphoramidite (heterocombinations) gave reduced yields and ee's in comparison with the phosphite alone, in all combinations except those containing either phosphoramidite $18-\mathrm{P}(\mathrm{O})_{2} \mathrm{~N}$ or 
19- $\mathrm{P}(\mathrm{O})_{2} \mathrm{~N}$. In these heterocombinations, considerably higher ee's and quantitative yields were obtained. In particular, $(R)-3$-phenylcyclohexanone $\mathbf{2 4}$ was obtained in $95 \%$ ee (100\% yield) with phosphoramidite 19- $\mathrm{P}(\mathrm{O})_{2} \mathrm{~N}$ and phosphite 6- $\mathrm{P}(\mathrm{O})_{2} \mathrm{O}$ (Table 1, entry 5), and in $91 \%$ ee (100\% yield) with phosphoramidite 19-P $(\mathrm{O})_{2} \mathrm{~N}$ and phosphite $9-\mathrm{P}(\mathrm{O})_{2} \mathrm{O}$ (Table 1, entry 6). In the latter case, the synergistic effect of the heterocombination with respect to the corresponding homocombinations is worth an additional $55 \%$ ee $\left[9-\mathrm{P}(\mathrm{O})_{2} \mathrm{O} 28 \%\right.$ ee, $19-\mathrm{P}(\mathrm{O})_{2} \mathrm{~N} 36 \%$ ee]. The mismatched combinations gave $(S)$-3-phenylcyclohexanone $\mathbf{2 4}$ in $70 \%$ ee (100\% yield) with phosphoramidite $\mathbf{1 8}-\mathrm{P}(\mathrm{O}){ }_{2} \mathrm{~N}$ and phosphite 6-P $(\mathrm{O})_{2} \mathrm{O}$ (Table 1, entry 7), and $87 \%$ ee (100\% yield) with phosphoramidite 18-P(O) ${ }_{2} \mathrm{~N}$ and phosphite 9- $\mathrm{P}(\mathrm{O})_{2} \mathrm{O}$ (Table 1, entry 8), showing that it is the phosphoramidite which determines the absolute configuration of the reaction product. Again, the synergistic effect of the heterocombination is remarkable. The effect of the ring-size was then evaluated. 2-Cyclopentenone 20 and 2-cycloheptenone 22 were investigated using all the homocombinations and several heterocombinations (see Table 1 for selected results). The best results were again obtained using the heterocombinations containing the 2,5-diphenylpyrrolidine phosphoramidites $\left[18-\mathrm{P}(\mathrm{O})_{2} \mathrm{~N}\right.$ or $\left.19-\mathrm{P}(\mathrm{O})_{2} \mathrm{~N}\right]$ (Table 1, entries 9-15). The matched combination 6-P $(\mathrm{O})_{2} \mathrm{O} / \mathbf{1 9}-\mathrm{P}(\mathrm{O})_{2} \mathrm{~N}$ afforded $(R)-3$-phenylcycloheptanone 25 in $90 \%$ ee (100\% yield) and $(R)-3$-phenylcyclopentanone 23 in $73 \%$ ee (100\% yield).

Table 1 Selected results from the screening of the collection of chiral phosphites and phosphoramidites (homo- and heterocombinations) in the Rh-catalyzed conjugate addition of phenylboronic acid to cyclic enones.

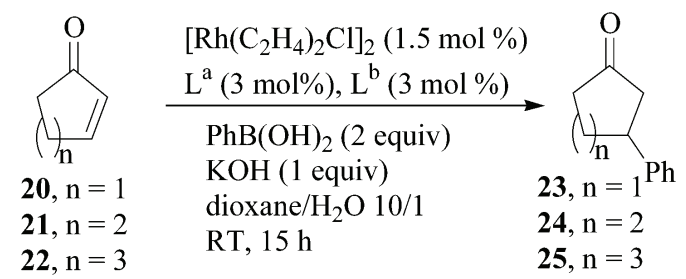

\begin{tabular}{|c|c|c|c|c|c|c|}
\hline Entry & Enone & $\mathrm{L}^{\mathrm{a}}$ & $\mathrm{L}^{\mathrm{b}}$ & Yield $(\%)^{\mathrm{a}}$ & ee $(\%)^{b}$ & Abs. config. \\
\hline 1 & 21 & 6-P $(\mathrm{O})_{2} \mathrm{O}$ & 6- $\mathrm{P}(\mathrm{O})_{2} \mathrm{O}$ & 100 & 70 & $R$ \\
\hline 2 & 21 & 9- $\mathrm{P}(\mathrm{O})_{2} \mathrm{O}$ & 9- $\mathrm{P}(\mathrm{O})_{2} \mathrm{O}$ & 100 & 28 & $R$ \\
\hline 3 & 21 & $18-\mathrm{P}(\mathrm{O})_{2} \mathrm{~N}$ & $18-\mathrm{P}(\mathrm{O})_{2} \mathrm{~N}$ & 100 & 36 & $S$ \\
\hline 4 & 21 & 19- $\mathrm{P}(\mathrm{O})_{2} \mathrm{~N}$ & 19- $\mathrm{P}(\mathrm{O}){ }_{2} \mathrm{~N}$ & 100 & 36 & $R$ \\
\hline 5 & 21 & 6- $\mathrm{P}(\mathrm{O})_{2} \mathrm{O}$ & $19-\mathrm{P}(\mathrm{O})_{2} \mathrm{~N}$ & 100 & 95 & $\boldsymbol{R}^{\mathrm{c}}$ \\
\hline 6 & 21 & 9-P(O) ${ }_{2} \mathrm{O}$ & 19- $\mathrm{P}(\mathrm{O}){ }_{2} \mathrm{~N}$ & 100 & 91 & $R$ \\
\hline 7 & 21 & 6- $\mathrm{P}(\mathrm{O})_{2} \mathrm{O}$ & $18-\mathrm{P}(\mathrm{O}){ }_{2} \mathrm{~N}$ & 100 & 70 & $S$ \\
\hline 8 & 21 & 9- $\mathrm{P}(\mathrm{O})_{2} \mathrm{O}$ & 18- $\mathrm{P}(\mathrm{O}){ }_{2} \mathrm{~N}$ & 100 & 87 & $S$ \\
\hline 9 & 22 & 9-P(O) ${ }_{2} \mathrm{O}$ & $18-\mathrm{P}(\mathrm{O}){ }_{2} \mathrm{~N}$ & 100 & 80 & $S$ \\
\hline 10 & 22 & $2-\mathrm{P}(\mathrm{O}){ }_{2} \mathrm{O}$ & 18- $\mathrm{P}(\mathrm{O}){ }_{2} \mathrm{~N}$ & 80 & 83 & $S$ \\
\hline 11 & 22 & 6- $\mathrm{P}(\mathrm{O})_{2} \mathrm{O}$ & 19- $\mathrm{P}(\mathrm{O}){ }_{2} \mathrm{~N}$ & 100 & 90 & $\boldsymbol{R}^{\mathrm{c}}$ \\
\hline 12 & 22 & 9- $\mathrm{P}(\mathrm{O})_{2} \mathrm{O}$ & 19- $\mathrm{P}(\mathrm{O}){ }_{2} \mathrm{~N}$ & 100 & 90 & $R$ \\
\hline 13 & 20 & 7-P(O) ${ }_{2} \mathrm{O}$ & $7-\mathrm{P}(\mathrm{O})_{2} \mathrm{O}$ & 100 & 58 & $S$ \\
\hline 14 & 20 & 6- $\mathrm{P}(\mathrm{O})_{2} \mathrm{O}$ & $19-\mathrm{P}(\mathrm{O})_{2} \mathrm{~N}$ & 100 & 73 & $\boldsymbol{R}^{\mathrm{c}}$ \\
\hline 15 & 20 & 9- $\mathrm{P}(\mathrm{O})_{2} \mathrm{O}$ & 19- $\mathrm{P}(\mathrm{O}){ }_{2} \mathrm{~N}$ & 100 & 68 & $R$ \\
\hline
\end{tabular}

${ }^{\mathrm{a}} \mathrm{GC}$ yield, using $n$-tridecane as internal standard.

betermined by GC. For 23: SUPELCO $\gamma$-DEX 225, $25 \mathrm{~m}$, film $0.25 \mu \mathrm{m}$, carrier $\mathrm{H}_{2}$. For 24 and 25 : MEGADEX DACTBS $\beta$, OV 1701, $25 \mathrm{~m}$, film $0.25 \mu \mathrm{m}$, carrier $\mathrm{H}_{2}$.

${ }^{\mathrm{c}}$ The combination of $18-\mathrm{P}(\mathrm{O})_{2} \mathrm{~N}$ and ent-6- $\mathrm{P}(\mathrm{O})_{2} \mathrm{O}$ gave the opposite enantiomer $(S)$ with the same yield and ee.

The remarkable increase of ee obtained with the 6-P(O) ${ }_{2} \mathrm{O} / \mathbf{1 9}-\mathrm{P}(\mathrm{O})_{2} \mathrm{~N}$ heterocombination compared to the single ligands, prompted us to study the tropos/atropos nature [3c] of the ligands in the $\mathrm{Rh}$ 
complex. The metal complexes containing biphenolic tropos ligands (phosphites or phosporamidites) were defined "induced atropisomeric" by Alexakis [3a] and "fluxionally atropisomeric" by Reetz [4c]. However, no proof was ever presented regarding their tropos or atropos nature. A variable-temperature ${ }^{31} \mathrm{P}-\mathrm{NMR}$ study of the ligands 6-P(O) ${ }_{2} \mathrm{O}$ and $19-\mathrm{P}(\mathrm{O})_{2} \mathrm{~N}$ and of the Rh complexes which originate from their homo- $\left(2 \mathrm{~L}^{\mathrm{a}}, 2 \mathrm{~L}^{\mathrm{b}}\right)$ and heterocombination $\left(\mathrm{L}^{\mathrm{a}}+\mathrm{L}^{\mathrm{b}}\right)$ was undertaken, using $\mathrm{Rh}(\mathrm{acac})\left(\mathrm{C}_{2} \mathrm{H}_{4}\right)_{2}$ as the metal source. ${ }^{31} \mathrm{P}-\mathrm{NMR}$ studies demonstrate the tropos nature of phosphite $6-\mathrm{P}(\mathrm{O})_{2} \mathrm{O}$ in the $\mathrm{Rh}$ complex even at low temperature $(230 \mathrm{~K})$, while the spectra of the Rh complex of phosphoramidite 19- $\mathrm{P}(\mathrm{O})_{2} \mathrm{~N}$ showed a typical coalescence behavior (coalescence temperature $T_{\mathrm{C}}=320 \mathrm{~K}$ in toluene- $\mathrm{d}_{8}$; $T_{\mathrm{C}}=290 \mathrm{~K}$ in dichloromethane- $\left.\mathrm{d}_{2}\right)[7 \mathrm{c}]$.

The spectra of the Rh complexes resulting from the combination of phosphite $6-\mathrm{P}(\mathrm{O})_{2} \mathrm{O}$ and phosphoramidite 19-P(O) ${ }_{2} \mathrm{~N}$ account for the presence of the $\mathrm{L}^{\mathrm{a}} \mathrm{RhL}^{\mathrm{a}}$ and $\mathrm{L}^{\mathrm{b}} \mathrm{RhL}^{\mathrm{b}}$ homocomplexes (ca. $40 \%$ ) and of the $\mathrm{L}^{\mathrm{a}} \mathrm{RhL}^{\mathrm{b}}$ heterocomplex (ca. $60 \%$ ) [6]. At $375 \mathrm{~K}$, the heterocomplex $\mathrm{L}^{\mathrm{a}} \mathrm{RhL}^{\mathrm{b}}$ has a tropos phosphite and a tropos phosphoramidite. The coalescence temperature $\left(T_{\mathrm{C}}\right)$ is $310 \mathrm{~K}$, and by cooling to $230 \mathrm{~K}$, it is possible to identify one of the two possible diastereomers differing for the configuration at the phosphoramidite atropisomeric biphenol (which can be a $R$ or a $S$ ), while the phosphite biphenol remains free to rotate (tropos). The free energy barrier to the biphenol rotation in the $\mathrm{L}^{\mathrm{a}} \mathrm{RhL}^{\mathrm{b}}$ heterocomplex was calculated in toluene- $\mathrm{d}_{8} \Delta \mathrm{G}^{\neq}=14.5 \pm 0.2 \mathrm{kcal} \mathrm{mol}^{-1}[7 \mathrm{c}]$.

In summary, of the 10 possible different precatalysts, we detected the presence of five species: four homocomplexes (total ca. $40 \%$ ) $\operatorname{Rh}\left[6-\mathrm{P}(\mathrm{O})_{2} \mathrm{O}\right]_{2}, \operatorname{Rh}\left[(\mathrm{a} R)-19-\mathrm{P}(\mathrm{O})_{2} \mathrm{~N}\right]_{2}, \operatorname{Rh}\left[(\mathrm{aS})-\mathbf{1 9}-\mathrm{P}(\mathrm{O})_{2} \mathrm{~N}\right]_{2}$, $\mathrm{Rh}\left[(\mathrm{a} R)-19-\mathrm{P}(\mathrm{O})_{2} \mathrm{~N}\right]\left[(\mathrm{a} S)-19-\mathrm{P}(\mathrm{O})_{2} \mathrm{~N}\right]$, and one heterocomplex (ca. $\left.60 \%\right) \operatorname{Rh}\left[\mathbf{6}-\mathrm{P}(\mathrm{O})_{2} \mathrm{O}\right][(\mathrm{a} R)-19-$ $\left.\mathrm{P}(\mathrm{O})_{2} \mathrm{~N}\right]$ or $\mathrm{Rh}\left[6-\mathrm{P}(\mathrm{O})_{2} \mathrm{O}\right]\left[(\mathrm{a} S)-19-\mathrm{P}(\mathrm{O})_{2} \mathrm{~N}\right]$. Performing the reaction at $298 \mathrm{~K}(15 \mathrm{~h}, 100 \%$ yield, $95 \%$ ee), near the heterocomplex coalescence temperature $(310 \mathrm{~K})$, seems particularly important. In fact, the ee slightly decreased at both $353 \mathrm{~K}(15 \mathrm{~h}, 100 \%$ yield, $86 \%$ ee) and $283 \mathrm{~K}(60 \mathrm{~h}, 100 \%$ yield, $93 \%$ ee). We also prepared the $(R)$ - and the $(S)$-binaphthol analogs of phosphoramidite $19-\mathrm{P}(\mathrm{O})_{2} \mathrm{~N}$ and tested each of them in combination with phosphite 6-P(O $)_{2} \mathrm{O}$. Surprisingly, the combination of 6-P(O) ${ }_{2} \mathrm{O}$ with either the $(S)$-binaphthol analog [50\% yield, $46 \%$ ee, $(R)]$ or the $(R)$-binaphthol analog [70\% yield, $72 \%$ ee, $(R)$ ] were both considerably less effective than the original biphenol-based combination [100\% yield, $95 \%$ ee, $(R)]$. These experiments further emphasize the role of the tropos/atropos biphenol near the coalescence temperature in promoting high enantioselectivities: a case where a conformationally mobile catalyst is capable of self-adaptation and substrate-matching better than a rigid system.

\section{RHODIUM-CATALYZED ASYMMETRIC HYDROGENATION}

The hydrogenation reactions were initially performed on methyl 2-acetamidoacrylate (in dichloromethane, overnight, at 1 bar hydrogen pressure, using $1 \mathrm{~mol} \%$ of $\mathrm{Rh}(\mathrm{COD})_{2} \mathrm{BF}_{4}$ and a total of $2 \mathrm{~mol} \%$ of ligands). The ligands were first screened individually (homocombinations): in general, the phosphites were much more reactive than the phosphoramidites, allowing for excellent yields and moderate ee's. By mixing two different phosphoramidite ligands, the hydrogenation product was generally obtained in moderate ee (lower than with the corresponding homocombinations), and poor conversion. The phosphite-phosphite combinations gave the product quantitatively, but with poor ee's. The phosphite-phosphoramidite combinations were the most productive, retaining the phosphite high reactivity (resulting in high conversions) and often improving the enantioselectivities compared to the homocombinations (for selected results, see Table 2). The best combination 4-P(O) $)_{2} \mathrm{O} / \mathbf{1 3}-\mathrm{P}(\mathrm{O})_{2} \mathrm{~N}$ (Table 2, entry 7) gave (S)- $N$-acetylalanine methyl ester in $87 \%$ ee (100\% yield), while the corresponding mismatched combination [4-P(O) $)_{2} \mathrm{O} / \mathbf{1 2}-\mathrm{P}(\mathrm{O})_{2} \mathrm{~N}$, Table 2, entry 6] gave $(R)-N$-acetylalanine methyl ester in $35 \%$ ee (100\% yield). The effect of the solvent was then studied, and it was noticed that the use of more polar solvents (THF, EtOAc, alcohols) was beneficial to the enantioselectivity of the reaction; in particular, when isopropanol was used, the product was obtained in $94 \%$ ee and $100 \%$ yield (Table 2, entry 9). Selected heterocombinations were also tested in the hydrogenation of 2-acetamidoacrylic acid: under the optimized conditions ( $\mathrm{irOH}$, room temperature, 1 bar hydrogen pressure, overnight) the 
combination of ligands 4-P(O) $)_{2} \mathrm{O}$ and $13-\mathrm{P}(\mathrm{O})_{2} \mathrm{~N}$ gave $(S)$ - $\mathrm{N}$-acetylalanine in $94 \%$ ee and $100 \%$ yield [7].

Table 2 Rh-catalyzed hydrogenation of methyl 2-acetamidoacrylate (selected results) ${ }^{\mathrm{a}}$.

\begin{tabular}{|c|c|c|c|c|c|c|}
\hline \multirow[b]{2}{*}{ Entry } & & ${ }_{2} \mathrm{Me} \quad \frac{\mathrm{Rh}(\mathrm{C}}{\mathrm{L}^{\mathrm{a}}(0.0)} \frac{\mathrm{H}_{2}(1)}{1}$ & $\begin{array}{l})_{2} \mathrm{BF}_{4}(0 . \\
\text { quiv), } \mathrm{L}^{\mathrm{b}} \text { (( }\end{array}$ & $\begin{array}{l}\text { equiv) } \\
1 \text { equiv) } \\
\stackrel{5}{{ }^{\circ} \mathrm{C}}\end{array}$ & $\overbrace{\mathrm{CO}_{2} \mathrm{MHAc}}^{\mathrm{NHAc}}$ & \\
\hline & $\mathrm{L}^{\mathrm{a}}$ & $\mathrm{L}^{\mathrm{b}}$ & Solvent & Yield (\%) & ee $(\%)$ & Abs. config. \\
\hline 1 & 3- $\mathrm{P}(\mathrm{O})_{2} \mathrm{O}$ & 3- $\mathrm{P}(\mathrm{O})_{2} \mathrm{O}$ & $\mathrm{CH}_{2} \mathrm{Cl}_{2}$ & 100 & 25 & $R$ \\
\hline 2 & 4- $\mathrm{P}(\mathrm{O})_{2} \mathrm{O}$ & 4- $\mathrm{P}(\mathrm{O})_{2} \mathrm{O}$ & $\mathrm{CH}_{2} \mathrm{Cl}_{2}$ & 80 & 53 & $S$ \\
\hline 3 & 5- $\mathrm{P}(\mathrm{O})_{2} \mathrm{O}$ & $5-\mathrm{P}(\mathrm{O})_{2} \mathrm{O}$ & $\mathrm{CH}_{2} \mathrm{Cl}_{2}$ & 100 & 55 & $R$ \\
\hline 4 & $12-\mathrm{P}(\mathrm{O})_{2} \mathrm{~N}$ & $12-\mathrm{P}(\mathrm{O})_{2} \mathrm{~N}$ & $\mathrm{CH}_{2} \mathrm{Cl}_{2}$ & 7 & 52 & $R$ \\
\hline 5 & $13-\mathrm{P}(\mathrm{O})_{2} \mathrm{~N}$ & $13-\mathrm{P}(\mathrm{O})_{2} \mathrm{~N}$ & $\mathrm{CH}_{2} \mathrm{Cl}_{2}$ & 7 & 52 & $S$ \\
\hline 6 & $4-\mathrm{P}(\mathrm{O})_{2} \mathrm{O}$ & $12-\mathrm{P}(\mathrm{O})_{2} \mathrm{~N}$ & $\mathrm{CH}_{2} \mathrm{Cl}_{2}^{2}$ & 100 & 35 & $R$ \\
\hline 7 & 4-P(O) ${ }_{2} \mathrm{O}$ & $13-\mathrm{P}(\mathrm{O})_{2} \mathrm{~N}$ & $\mathrm{CH}_{2} \mathrm{Cl}_{2}$ & 100 & 87 & $S$ \\
\hline 8 & 4- $\mathrm{P}(\mathrm{O})_{2} \mathrm{O}$ & $13-\mathrm{P}(\mathrm{O})_{2} \mathrm{~N}$ & $\mathrm{MeOH}$ & 100 & 88 & $S$ \\
\hline 9 & 4-P(O) ${ }_{2} \mathrm{O}$ & $13-\mathrm{P}(\mathrm{O})_{2} \mathrm{~N}$ & $i \operatorname{PrOH}$ & 100 & 94 & $S$ \\
\hline 10 & 4- $\mathrm{P}(\mathrm{O})_{2} \mathrm{O}$ & $13-\mathrm{P}(\mathrm{O})_{2} \mathrm{~N}$ & EtOAc & 100 & 91 & $S$ \\
\hline 11 & 3- $\mathrm{P}(\mathrm{O})_{2} \mathrm{O}$ & $13-\mathrm{P}(\mathrm{O})_{2} \mathrm{~N}$ & $\mathrm{CH}_{2} \mathrm{Cl}_{2}$ & 40 & 73 & $S$ \\
\hline
\end{tabular}

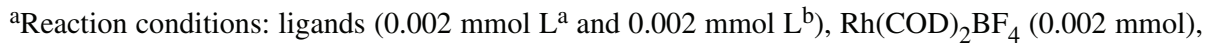
methyl 2-acetamidoacrylate $(0.2 \mathrm{mmol})$, solvent $(2.0 \mathrm{ml}), \mathrm{H}_{2}(1 \mathrm{bar}), \mathrm{RT}, 60 \mathrm{~h}$. Yields and ee's were determined by GC equipped with a chiral capillary column (MEGADEX DACTBS $\beta$ ) using $n$-tridecane as internal standard.

Further experiments were carried out in collaboration with Prof. J. G. de Vries, Dr. A. H. M. de Vries, and Dr. L. Lefort (DSM Pharma Chemicals—Advanced Synthesis, Catalysis, and Development) [7b]. For the hydrogenation of methyl 2-acetamidocinnamate, the ligand screening was performed with a Premex-96 multireactor (room temperature in dichloromethane, with 10 bar hydrogen pressure). The homocombinations gave results ranging from $6 \%$ ee and $2 \%$ conversion [Table 3 , entry $2,13-\mathrm{P}(\mathrm{O})_{2} \mathrm{~N}$ ] to $64 \%$ ee and $100 \%$ conversion [Table 3 , entry $1,4-\mathrm{P}(\mathrm{O})_{2} \mathrm{O}$ ]. The best result was obtained with the heterocombination of ligands $4-\mathrm{P}(\mathrm{O})_{2} \mathrm{O}$ and $13-\mathrm{P}(\mathrm{O})_{2} \mathrm{~N}$, allowing for $85 \%$ ee and $82 \%$ conversion (Table 3, entry 3).

The solvent screening was carried out using a multireactor autoclave (Argonaut Endeavor ${ }^{\mathrm{TM}}$ ): in particular, isopropanol allowed for $95 \%$ ee and $100 \%$ conversion at 5 bar hydrogen pressure (Table 3 , entry 4) $[7 b]$.

Also for the hydrogenation of 2-acetamidocinnamic acid, excellent results were obtained with the combination 4-P(O) $)_{2} \mathrm{O} / \mathbf{1 3}-\mathrm{P}(\mathrm{O})_{2} \mathrm{~N}$ (93\% ee, $100 \%$ conversion). Substituted 2-acetamidocinnamic acids were then tested using the heterocombination 4-P(O) ${ }_{2} \mathrm{O}$ and $13-\mathrm{P}(\mathrm{O})_{2} \mathrm{~N}$. The introduction of a $\mathrm{Cl}$ substituent in the phenyl ring resulted in a significant increase of the enantioselectivity: excellent enantioselectivities and quantitative conversions were obtained in $i \mathrm{PrOH}$ with both $\mathrm{N}$-acetyl-2chlorodehydrophenylalanine [ $100 \%$ yield, $98 \%$ ee $(S)$ at 10 bar and $100 \%$ yield, $95 \%$ ee $(S)$ at 25 bar] and $\mathrm{N}$-acetyl-4-chlorodehydrophenylalanine [100\% yield, $97 \%$ ee $(S)$ at $10 \mathrm{bar}$ ] as substrates [7b].

The enantioselective hydrogenation of $\beta$-acylamino acrylates gives access to chiral $\beta$-amino acid derivatives which are important pharmaceutical building blocks. For this reason, the ligand library was screened in the hydrogenation of methyl $(Z)-3$-acetamidocrotonate $\left[\mathrm{Rh}(\mathrm{COD})_{2} \mathrm{BF}_{4}, i \mathrm{PrOH}, 25\right.$ bar hydrogen pressure]. The heterocombination $3-\mathrm{P}(\mathrm{O})_{2} \mathrm{O} / \mathbf{1 9}-\mathrm{P}(\mathrm{O})_{2} \mathrm{~N}$ gave the best result $[71 \%$ ee $(R), 100 \%$ yield] [7b]. 
Table 3 Rh-catalyzed hydrogenation of methyl 2-acetamidocinnamate (selected results) ${ }^{\mathrm{a}}$.

\begin{tabular}{|c|c|c|c|c|c|c|}
\hline \multirow[b]{2}{*}{ Entry } & $\mathrm{Ph}=<_{\mathrm{CO}_{2} \mathrm{Me}}^{\mathrm{NHAc}}$ & $\mathrm{J}_{2} \mathrm{Me} \frac{\begin{array}{r}\mathrm{Rh}(\mathrm{C} \\
\mathrm{L}^{\mathrm{a}}(0.0\end{array}}{\mathrm{H}_{2}(1}$ & $\begin{array}{l})_{2} \mathrm{BF}_{4}(0 . \\
\text { quiv), } \mathrm{L}^{\mathrm{b}}( \\
\text { bar), Solve }\end{array}$ & $\underset{25{ }^{\circ} \mathrm{C}}{\stackrel{\text { equiv) }}{1 \text { equiv) }} \mathrm{P}}$ & $s_{5} \mathrm{NHAC}$ & \\
\hline & $\mathrm{L}^{\mathrm{a}}$ & $\mathrm{L}^{\mathrm{b}}$ & Solvent & Yield (\%) & ee $(\%)$ & Abs. config. \\
\hline 1 & 4- $\mathrm{P}(\mathrm{O})_{2} \mathrm{O}$ & $4-\mathrm{P}(\mathrm{O})_{2} \mathrm{O}$ & $\mathrm{CH}_{2} \mathrm{Cl}_{2}$ & 100 & 64 & $S$ \\
\hline 2 & $13-\mathrm{P}(\mathrm{O})_{2} \mathrm{~N}$ & $13-\mathrm{P}(\mathrm{O})_{2} \mathrm{~N}$ & $\mathrm{CH}_{2} \mathrm{Cl}_{2}$ & 2 & 6 & $S$ \\
\hline 3 & 4-P(O) $)_{2} \mathrm{O}$ & $13-\mathrm{P}(\mathrm{O}){ }_{2} \mathrm{~N}$ & $\mathrm{CH}_{2} \mathrm{Cl}_{2}$ & 82 & 85 & $S$ \\
\hline $4^{b}$ & 4- $\mathrm{P}(\mathrm{O})_{2} \mathrm{O}$ & $13-\mathrm{P}(\mathrm{O}){ }_{2} \mathrm{~N}$ & iPrOH & 100 & 95 & $S$ \\
\hline 5 & $5-\mathrm{P}(\mathrm{O})_{2} \mathrm{~N}$ & $19-\mathrm{P}(\mathrm{O})_{2} \mathrm{~N}$ & $\mathrm{CH}_{2} \mathrm{Cl}_{2}$ & 100 & 69 & $R$ \\
\hline 6 & 6- $\mathrm{P}(\mathrm{O})_{2} \mathrm{O}$ & $19-\mathrm{P}(\mathrm{O})_{2} \mathrm{~N}$ & $\mathrm{CH}_{2} \mathrm{Cl}_{2}$ & 100 & 64 & $R$ \\
\hline
\end{tabular}

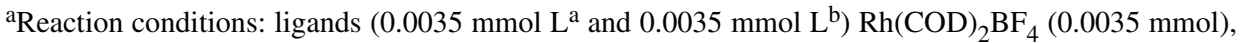
methyl 2-acetamidocinnamate $(0.175 \mathrm{mmol})$, solvent $(2.5 \mathrm{ml}) \mathrm{H}_{2}(10 \mathrm{bar}), \mathrm{RT}, 16 \mathrm{~h}$. Yields and ee's were determined by GC equipped with a chiral capillary column (CP-Chirasil- $L$-Val). ${ }^{\mathrm{b}} \mathrm{H}_{2}$ (5 bar).

\section{Rate comparisons and improvement of the heterocombination ligand ratio}

A comparison of the rates of the hydrogenation of methyl 2-acetamidocinnamate using single ligands 4- $\mathrm{P}(\mathrm{O})_{2} \mathrm{O}$ and 13- $\mathrm{P}(\mathrm{O})_{2} \mathrm{~N}$ and their heterocombination proved that phosphite 4-P $(\mathrm{O})_{2} \mathrm{O}$ was the most active (with full conversion within $30 \mathrm{~min}$ and $79 \%$ ee), while phosphoramidite $13-\mathrm{P}(\mathrm{O})_{2} \mathrm{~N}$ was much slower ( $3 \%$ conversion in $5 \mathrm{~h}, 36 \%$ ee). When the $1: 1$ heterocombination of ligands $4-\mathrm{P}(\mathrm{O})_{2} \mathrm{O}$ and 13- $\mathrm{P}(\mathrm{O})_{2} \mathrm{~N}$ was employed, the highest enantioselectivity (95\% ee) was obtained with complete conversion in $2 \mathrm{~h}$ (definitely slower than the phosphite-catalyzed, but much faster than the phosphoramidite-catalyzed reaction).

We envisaged that, by modifying the $\mathrm{L}^{\mathrm{a}}: \mathrm{L}^{\mathrm{b}}$ ratio, we could influence the concentration of the different species and possibly the stereochemical outcome of the reaction. In particular, we speculated that lowering the ratio 4-P(O) $)_{2} \mathrm{O}: 13-\mathrm{P}(\mathrm{O})_{2} \mathrm{~N}$, but keeping constant the $\left(\mathrm{L}^{\mathrm{a}}+\mathrm{L}^{\mathrm{b}}\right): \mathrm{Rh}$ ratio (equal to 2), less Rh complex containing only 4-P(O) $)_{2} \mathrm{O}$ (very active, but less enantioselective) would be present in solution. This would in turn favor the concentration of mixed complexes containing both 4-P(O) ${ }_{2} \mathrm{O}$ and 13- $\mathrm{P}(\mathrm{O})_{2} \mathrm{~N}$, apparently the most selective ones. The species containing only $13-\mathrm{P}(\mathrm{O})_{2} \mathrm{~N}$ would become predominant but, being almost inactive, should not influence significantly the reaction outcome. A screening of the relative ratio of the two ligands was carried out in isopropanol. The best $\mathrm{L}^{\mathrm{a}}: \mathrm{L}^{\mathrm{b}}$ ratio identified was $0.25: 1.75$ for $4-\mathrm{P}(\mathrm{O})_{2} \mathrm{O}$ and $13-\mathrm{P}(\mathrm{O})_{2} \mathrm{~N}$, respectively, which gave the hydrogenation product in $98 \%$ ee and $79 \%$ conversion $(i \mathrm{PrOH}$ as solvent: $79 \%$ ee and $100 \%$ conversion with 4- $\mathrm{P}(\mathrm{O})_{2} \mathrm{O} ; 36 \%$ ee and $2 \%$ conversion with and $13-\mathrm{P}(\mathrm{O})_{2} \mathrm{~N} ; 95 \%$ ee and $100 \%$ conversion with a $1: 1$ ratio of $4-\mathrm{P}(\mathrm{O})_{2} \mathrm{O}$ and $\left.\mathbf{1 3}-\mathrm{P}(\mathrm{O})_{2} \mathrm{~N}\right)[7 \mathrm{~b}]$.

The same study was then performed for the hydrogenation of methyl 2-acetamidoacrylate, and similar trends to those identified in the hydrogenation of methyl 2-acetamidocinnamate were observed. The best $\mathrm{L}^{\mathrm{a}}: \mathrm{L}^{\mathrm{b}}$ ratio identified was again $0.25: 1.75$ for $4-\mathrm{P}(\mathrm{O})_{2} \mathrm{O}$ and $13-\mathrm{P}(\mathrm{O})_{2} \mathrm{~N}$, respectively, allowing for $98 \%$ ee and $100 \%$ conversion $(i \mathrm{PrOH}$ as solvent: $61 \%$ ee and $100 \%$ conversion with 4- $\mathrm{P}(\mathrm{O})_{2} \mathrm{O} ; 89 \%$ ee and $3 \%$ conversion with $13-\mathrm{P}(\mathrm{O})_{2} \mathrm{~N} ; 94 \%$ ee and $100 \%$ conversion with a $1: 1$ ratio of 4-P(O) $)_{2} \mathrm{O}$ and $\left.13-\mathrm{P}(\mathrm{O})_{2} \mathrm{~N}\right)[7 \mathrm{~b}]$.

When the rates of the hydrogenation of methyl (Z)-3-acetamidocrotonate using ligands $3-\mathrm{P}(\mathrm{O})_{2} \mathrm{O}$, 19- $\mathrm{P}(\mathrm{O})_{2} \mathrm{~N}$, and their heterocombination were measured by hydrogen uptake, a different behavior was displayed: in this case, both phosphite 3-P(O) $)_{2} \mathrm{O}$ and phosphoramidite $19-\mathrm{P}(\mathrm{O})_{2} \mathrm{~N}$ give rise to very active catalysts, that allow for full conversion within $1 \mathrm{~h}$, while the reaction performed using the heterocombination is slower, although more enantioselective. 
This result was confirmed by the study of the relative ratio of the two ligands ( $i \mathrm{PrOH}$ at 25 bar hydrogen pressure), which showed that the $1: 1$ ratio $3-\mathrm{P}(\mathrm{O})_{2} \mathrm{O} / \mathbf{1 9}-\mathrm{P}(\mathrm{O})_{2} \mathrm{~N}$ was the most effective, both in terms of enantioselectivity and conversion ( $71 \%$ ee, $100 \%$ conversion). An excess of either one of the two ligands reduces the overall enantioselectivity [ $i \mathrm{PrOH}$ as solvent: $19 \%$ ee and $100 \%$ conversion with 3-P(O) $)_{2} \mathrm{O} ; 22 \%$ ee and $91 \%$ conversion with and $19-\mathrm{P}(\mathrm{O})_{2} \mathrm{~N} ; 60 \%$ ee and $83 \%$ conversion with a 0.5:1.5 ratio 3-P(O) $\left.)_{2} \mathrm{O} / \mathbf{1 9}-\mathrm{P}(\mathrm{O})_{2} \mathrm{~N}\right][7 \mathrm{~b}]$.

A simple mathematical model for a better understanding of the variation of the ee with the phosphite/phosphoramidite ratio was developed [7b]. The model can be used to fit the experimental data and consequently provides semiquantitative information on values that are not accessible via the experience, such as the rate of the heterocomplexes relative to the rate of the homocomplexes. It also allows an estimation of the distribution of the homo/heterocomplexes. The model also gives guidelines whether it is pertinent to screen outside the ratio of 1:1 for the ligands and how much improvement could be expected by doing so. In summary, the new concept of using a nonequivalent amount of the two ligands (while keeping total $\mathrm{L}: \mathrm{Rh}=2$ ) is a novel powerful tool to enhance enantioselectivity in selected cases.

\section{ACKNOWLEDGMENTS}

We thank the European Commission for financial support ("Enantioselective Recognition" HPRN-CT2001-00182), Merck Research Laboratories (Merck's Academic Development Program Award to C. Gennari), and Università di Milano for financial support and for a postdoctoral fellowship to C. Monti.

\section{REFERENCES}

1. For a recent review, see: W. Tang and X. Zhang. Chem. Rev. 103, 3029-3069 (2003).

2. (a) For a recent review, see: T. Jerphagnon, J.-L. Renaud, C. Bruneau. Tetrahedron: Asymmetry 15, 2101-2111 (2004); see also: (b) D. Peña, A. J. Minnaard, A. H. M. de Vries, J. G. de Vries, B. L. Feringa. Org. Lett. 5, 475-478 (2003) and refs. therein.

3. (a) A. Alexakis, S. Rosset, J. Allamand, S. March, F. Guillen, C. Benhaim. Synlett 1375-1378 (2001); (b) W. Chen and J. Xiao. Tetrahedron Lett. 42, 8737-8740 (2001); (c) for an account on atropos/tropos ligands, see: K. Mikami, K. Aikawa, Y. Yusa, J. J. Jodry, M. Yamanaka. Synlett 1561-1578 (2002).

4. (a) M. T. Reetz, T. Sell, A. Meiswinkel, G. Mehler. Angew. Chem., Int. Ed. 42, 790-793 (2003); (b) M. T. Reetz and G. Mehler. Tetrahedron Lett. 44, 4593-4596 (2003); (c) M. T. Reetz and X. Li. Angew. Chem., Int. Ed. 44, 2959-2962 (2005).

5. (a) D. Peña, A. J. Minnaard, J. A. F. Boogers, A. H. M. de Vries, J. G. de Vries, B. L. Feringa. Org. Biomol. Chem. 1, 1087-1089 (2003); (b) A. Duursma, D. Peña, A. J. Minnaard, B. L. Feringa. Tetrahedron: Asymmetry 16, 1901-1904 (2005); (c) R. Hoen, J. A. F. Boogers, H. Bernsmann, A. J. Minnaard, A. Meetsma, T. D. Tiemersma-Wegman, A. H. M. de Vries, J. G. de Vries, B. L. Feringa. Angew. Chem., Int. Ed. 44, 4209-4212 (2005).

6. The heterocomplex:homocomplex ratios usually exceed the statistical value, see: A. Duursma, R. Hoen, J. Schuppan, R. Hulst, A. J. Minnaard, B. L. Feringa. Org. Lett. 5, 3111-3113 (2003).

7. (a) C. Monti, C. Gennari, U. Piarulli. Tetrahedron Lett. 45, 6859-6862 (2004); (b) C. Monti, C. Gennari, U. Piarulli, J. G. de Vries, A. H. M. de Vries, L. Lefort. Chem. Eur. J. 11, 6701-6717 (2005); (c) C. Monti, C. Gennari, U. Piarulli. Chem. Commun. 5281-5283 (2005).

8. T. Hayashi and K. Yamasaki. Chem. Rev. 103, 2829-2844 (2003).

9. J. G. Boiteau, F. Imbos, A. J. Minnaard, B. L. Feringa. Org. Lett. 5, 681-684, 1385 (2003).

10. S. Sakuma and N. Miyaura. J. Org. Chem. 66, 8944-8946 (2001). 